Ks. Andrzej UCIECHA*

\title{
STEPHAN SCHIWIETZ (SIWIEC) - UCZEŃ W SZKOLE MAXA SDRALKA
}

Celem artykułu jest przypomnienie sylwetki i dorobku śląskiego historyka i teologa ks. dra Stefana Siwca, którego 70. rocznica śmierci przypadła 26 kwietnia 2011 roku. Naszym zamierzeniem jest przede wszystkim prezentacja osiagnięć naukowych Siwca, pragniemy także podjąć próbę charakterystyki metody badań, którą posługiwał się Siwiec, a którą w studiach historii Kościoła zapoczątkował jego nauczyciel z Uniwersytetu Wrocławskiego - ks. prof. Max Sdralek. Pracom tego ostatniego naukowca należało poświęcić więcej uwagi, jako że jego postać jest ściśle związana z osiagnięciami tak zwanej „wrocławskiej szkoły historycznej” (die Breslauer kirchengeschichtliche Schule). W analizach wpływu mistrza na ucznia nie chodzi o całościowe opracowania tematu, ale raczej o zaproszenie do dalszych poszukiwań i dyskusji.

1. Stephan Schiwietz (Siwiec) - życie i twórczość. Stephan Schiwietz (Stefan Siwiec) 1863-1941, ksiądz rzymskokatolicki, doktor teologii, historyk Kościoła Wschodniego, pedagog. Urodził się w Miasteczku Śląskim (Georgenberg) dnia 23 sierpnia 1863 r. Trzy lata studiował teologię na Uniwersytecie Wrocławskim (1881-1884) pod kierunkiem m.in. Hugo Laemmera, Ferdinanda Probsta, Artura Königa i Maxa Sdralka. Studia teologiczne kontynuował w Insbrucku (1884-1886), gdzie był uczniem Josepha Jungmanna i Gustava Bickella. Alumnat (1885-1886) spędził w Freising w Bawarii i tam przyjął święcenia kapłańskie w 1886 r. Swój doktorat Siwiec opublikował we Wrocławiu w 1896 r., a więc wtedy, gdy w tamtejszym uniwersytecie Max Sdralek objął Katedrę Historii Kościoła. Śląski badacz rozprawę doktorską poświęcił monastycznej reformie Teodora Studyty: De S. Theodoro Studita reformatore monachorum Basilianorum ${ }^{1}$.

Pracę katechety i nauczyciela matematyki w Państwowym Gimnazjum w Raciborzu Siwiec łączył z naukowymi poszukiwaniami w dziedzinie

${ }^{*}$ Ks. dr hab. Andrzej Uciecha - adiunkt w Katedrze Teologii Patrystycznej i Historii Kościoła na Wydziale Teologicznym Uniwersytetu Śląskiego w Katowicach; e-mail: andrzej.uciecha@wp.pl.

${ }^{1}$ S. Schiwietz, De S. Theodoro Studita reformatore monachorum Basilianorum, Vratislav 1896, praca dostępna: http://archive.org/stream/destheodorostud00schigoog\#page/n4/mode/2up [dostęp: 07.07.2013]. 
historii chrześcijaństwa wschodniego, zwłaszcza monastycyzmu. Wyniki swoich badań publikował po niemiecku, ale także po polsku. Najważniejsze jego dzieło na temat historii powstania i rozwoju monastycyzmu orientalnego do IV w. na terenach Egiptu, Palestyny, Syrii i Persji stanowi trzytomowa monografia Das morgenländische Mönchtum (Bd. 1: Das Ascetentum der drei ersten christl. Jahrhunderte und das egyptische Mönchtum im vierten Jahrhundert, Mainz 1904; Bd. 2: Das Mönchtum auf Sinai und in Palästina im 4 Jahrhundert, Mainz 1913; Bd. 3: Das Mönchtum in Syrien und Mesopotamien und das Aszetentum in Persien vierten Jarhundert, Mödling bei Wien 1938), cytowana do dziś w światowej literaturze patrystycznej. Twórczość naukowa Siwca pozostaje ciagle mało znana zwłaszcza w kręgu historyków starożytności i patrologów polskich. W 1943 r., a więc pięć lat po wydaniu trzeciego tomu monastycznej trylogii Siwca, ukazała się recenzja Jeana Gouillarda we francuskim „Études Byzantines”2. W najbardziej gruntownym do tej pory polskim opracowaniu monastycznego dorobku tego śląskiego orientalisty: Ks. dr Stefan Siwiec jako badacz wschodniego monastycyzmu, Wincenty Myszor zachęca współczesnych historyków: „Skromny dyrektor polskiego Gimnazjum w Rybniku, autor niemieckiego opracowania wschodniego monastycyzmu, dobrze znany do dzisiaj w nauce światowej, godzien jest tego, aby wyniki jego badań uwzględniali także polscy historycy, gdyż cytując francuskich, amerykańskich lub niemieckich uczonych, bardzo często dopiero wtedy zapoznają się z osiąnnięciami śląskiego badacza"”. Myszor podkreśla walor teologiczno-historyczny w opracowaniach Siwca, równocześnie jednak zauważa w jego analizach źródeł monastycyzmu wschodniego brak aspektu religioznawczego, zwłaszcza związku z manicheizmem ${ }^{4}$. Cenny przyczynek przybliżający sylwetkę tego Ślązaka należy traktować jako inspirację do dalszych poszukiwaniach.

Należy wspomnieć, że 8 listopada 2011 r. na Wydziale Teologicznym Uniwersytetu Śląskiego w Katowicach odbyła się konferencja naukowa pt. Historia monastycyzmu orientalnego. W 70 rocznice śmierci ks. dra Stefana Siwca (Schiwietz) 1863-19415, a jej pokłosiem było wydanie publikacji pod tym

${ }^{2}$ Por. J. Gouillard, [rec.] Schiwietz (Stephan), Das morgenländische Mönchtum. Dritter Band: Das Mönchtum in Syrien und Mesopotamien und das Aszetentum in Persien vierten Jarhundert, Mödling bei Wien 1938, EtByz 1 (1943) 285-286, http://www.persee.fr/web/revues/home/prescript/ article/rebyz_0258-2880_1943_num_1_1_910_t1_0285_0000_2 [dostęp: 07.07.2013].

${ }^{3}$ W. Myszor, Ks. dr Stefan Siwiec jako badacz wschodniego monastycyzmu, w: Kultura edukacyjna na Górnym Ślasku, red. A. Barciak, Katowice 2002, 304.

${ }^{4}$ Por. tamże, s. 304.

${ }^{5}$ Konferencję zorganizował Zakład Teologii Patrystycznej i Historii Kościoła w celu przypomnienia naukowego dorobku Siwca. Referaty wygłosili: ks. prof. dr hab. Janusz Królikowski (UJPII): Monastycyzm egipski w ujęciu ks. Stefana Siwca, ks. dr hab. Leon Nieścior (UKSW): Monastycyzm palestyńsko-synajski w ujęciu ks. Stefana Siwca, ks. dr hab. Jan Żelazny (UJPII): Monastycyzm syryjski i mezopotamski w ujęciu ks. Stefana Siwca i ks. dr Arkadiusz Jasiewicz: Św. Teodor 
samym tytułem w serii „Studia Antiquitatis Christianae. Series Nova” $16^{6}$. W opracowaniu tym umieszczony został materiał, który podzielono na trzy części. W pierwszej znalazły się artykuły, w których zostały zebrane i przeanalizowane teologiczne, historyczne i patrystyczne osiagnięcia Siwca zamieszczone w dziele jego życia Das morgenländische Mönchtum ${ }^{7}$. W drugiej części stanowiącej Aneks I zamieszczono materiały źródłowe wybranych prac samego Siwca, w tym jego rozprawę doktorską; następnie interesujący, ale mało znany przyczynek poświęcony orygenesowskim wpływom w eschatologii św. Jana Chryzostoma (Die Eschatologie des heiligen Johannes Chrysostomus und ihr Verhältnis zu der origenistischen ${ }^{8}$ ); oraz dwa artykuły, które opublikował we lwowskim „Przeglądzie Teologicznym”. Te ostatnie wydane po polsku nie zostały do tej pory omówione. Chodzi o pochodzący z $1924 \mathrm{r}$. Dotad nieuwzględnione świadectwo dotyczace sakramentu olejem namaszczenia. Dogmatyczno-historyczny przyczynek z historii Kościoła egipskiego ${ }^{9}$ oraz zredagowany w Rybniku w 1926 r. Nowy sposób wyjaśnienia tekstu 1Kor 7, 36-38 $8^{10}$. Brakuje z pewnością interesujących opracowań o charakterze pastoralno-pedagogicznym, wydanych jeszcze w Raciborzu: Methode des katholischen Religionsunterrichts auf der unteren, mittleren und oberen Stufe der kath. Lehranstalten (Ratibor 1899) oraz Zehn Betrachtungen auf das Fest der hl. Ursula und ihrer Gefährtinnen (Ratibor 1906). W formie rekompensaty włączono interesujący artykuł Felixa Hasse Die Aufgaben des Kirchengeschichtslehrers nach Professor Max Sdralek, który celowo zamieszczony został w trzeciej części opracowania jako wprowadzenie do dyskusji na temat ewentualnego wpływu tzw. ,wrocławskiej szkoły historycznej” (die Breslauer kirchengeschichtliche Schule) profesora Maxa Sdralka na badania Siwca ${ }^{11}$. Otóż równie mało znana postać i dorobek pochodzącego z Woszczyc innego śląskiego księdza-naukowca, rektora Uniwersytetu Wrocławskiego, Maksymiliana Sdralka, stanowi istotny kontekst metody badań, którą zapoczątkował, rozwijał i starał się przekazać swoim uczniom w tym także Stefanowi

Studyta jako reformator życia monastycznego w ujęciu ks. Stefana Siwca. III tom monografii Siwca (Das morgenländische Mönchtum, Bd. 3: Das Mönchtum in Syrien und Mesopotamien und das Aszetentum in Persien vierten Jarhundert) został zdigitalizowany i jest już dostępny w zbiorach biblioteki cyfrowej http://digital.fides.org.pl/dlibra/docmetadata?id=1463 [dostęp: 07.07.2013].

${ }^{6}$ Historia monastycyzmu orientalnego. W 70 rocznicę śmierci ks. dra Stefana Siwca (Schiwietz) 1863-1941, red. A. Uciecha, SACh SN 16, Katowice 2014.

${ }^{7}$ Warto zaznaczyć, że prof. Ewa Wipszycka doceniła monastyczny dorobek śląskiego orientalisty, umieszczając 1. tom Das morgenländische Mönchtum w bibliografii: Pachomiana graeca. Vita graeca prima. List Ammona. Paralipomena, ŹM 65, Kraków - Tyniec 2013, 110.

${ }^{8}$ Mainz 1914.

${ }^{9}$ PT 5 (1924) 236-246.

10 PT 7 (1926) 225-239. Oba artykuły http://www.dbc.wroc.pl/publication/4033 [dostęp: 07.07.2013]

${ }^{11}$ Por. R. Bendel, Max Sdralek. Der Begründer der Breslauer kirchenhistorischen Schule, „Archiv für schlesische Kirchengeschichte" 55 (1997) 11-38. 
Siwcowi, tenże uczony. Sdralek rygorystycznie wymagał zachowania zasady pierwszeństwa historii Kościoła przed historią religii i psychologii. W jego pracach opis czynników społeczno-kulturowych i naturalnych warunków procesu rozwoju chrześcijaństwa pozwala o wiele jaśniej uwydatnić znaczenie teologicznej interpretacji wydarzeń historycznych. Ciekawa pozostaje kwestia podobieństw i zależności w sposobie uprawiania i pojmowania historii Kościoła Sdralka i Siwca. W ramach badań porównawczych przeanalizowane zostały wybrane fragmenty wspomnianej już monastycznej trylogii Siwca oraz dwóch artykułów, które opublikował we lwowskim „Przeglądzie Teologicznym”. Należy zaznaczyć, że w przedstawionych analizach porównawczych nie mamy zamiaru podać całościowego i wyczerpującego opracowania tematu, chcemy go jedynie zasygnalizować. Podkreślić także należy charakter przyjętej metody badawczej, w której proponujemy wykorzystać najbardziej zwięzły, precyzyjny i reprezentatywny opis warsztatu naukowego Sdralka przedstawiony przez jego wybitnego ucznia Felixa Hasse ${ }^{12}$. Na samym początku swojego przedłożenia Hasse wprost nazywa je nekrologiem (Nachruf), nie wiadomo jednak, czy chodzi o mowę wygłoszoną w czasie pogrzebu Sdralka (2 VII 1913), czy raczej o recenzję jego naukowego i duszpasterskiego dorobku (publikacja ukazała się w 1914 roku) ${ }^{13}$.

Współczesne próby scharakteryzowania metody historycznej Sdralka podjęli badacze niemieccy Rainer Bendel ${ }^{14}$ i Hubert Schiel ${ }^{15}$. Ten pierwszy przywołuje opinię Huberta Jedina, który scharakteryzował Sdralka jako „das Haupt einer ausgebreitenen Schule"16 . Krótkie wzmianki w formie haseł encyklopedycznych na temat Sdralka podają Hans-Ludwig Abmeier ${ }^{17}$ oraz Manfred Weitlauff ${ }^{18}$.

${ }^{12}$ Por. F. Hasse, Die Aufgaben des Kirchengeschichtslehrers nach Professor Max Sdralek, Schlesisches Pastoralblatt 35, Breslau 1914, 8-12 i 17-21, dostępne także jako osobna publikacja pod tym samym tytułem http://www.europeana.eu/portal/record/09404/19E73F2EA879B11F6E4B7787FB8D42480734A371.html [dostęp: 07.07.2013]. Korzystamy z tej ostatniej wersji. Krótki biogram Sdralka podaje inny wybitny jego uczeń Joseph Wittig (Max Sdralek, Schlesier 1, Schlesier des 19. Jahrhunderts, hrsg. von F. Andreae - M. Hippe - O. Schwarzer, Breslau 1922, 130-133.

${ }^{13}$ Por. Hasse, Die Aufgaben des Kirchengeschichtslehrers, s. 4. Hasse wspomina o swojej krótkiej wzmiance na temat życia i twórczości Sdralka w artykule Leben und Schriften der kath.-theol. Dozenten an der Universität Breslau, Breslau 1913, 127-128 i 149-150.

${ }^{14}$ Por. Bendel, Max Sdralek, s. 11-38.

${ }^{15}$ Por. H. Schiel, Max Sdralek, der Begründer der Breslauer Kirchengeschichtsschule, im Bannkreis von Xaver Kraus, Teil 1, „Archiv für schlesische Kirchengeschichte” 35 (1977) 239-284.

${ }^{16}$ Bendel, Max Sdralek, s. 11. Por. H. Jedin, Kirchenhistoriker aus Schlesien in der Ferne, „Archiv für schlesische Kirchengeschichte" 11 (1963) 250.

${ }^{17}$ Por. H.-L. Abmeier, Sdralek, Max Lukas, http://kulturportal-west-ost.eu/biographies/sdralek-max-lukas-2/ [dostęp: 07.07.2013].

${ }^{18}$ Por. M. Weitlauff, Sdralek Max, w: Neue Deutsche Biographie, t. 24, Berlin 2010, 103, praca dostępna: http://www.deutsche-biographie.de/sfz120586.html [dostęp: 07.07.2013]. 
2. Historia Kościoła i personalizm w metodzie M. Sdralka. Opisując kontekst przemian polityczno-społecznych zachodzących w połowie XIX w., Bendel podkreśla, że w oczach Sdralka do wzrostu znaczenia nauk historycznych przyczynił się czynnik nacjonalizacji polityki. Zmiany objęły także pojmowanie i rolę filozofii, która w myśli Immanuela Kanta zajmowała pozycję centralną w nauce, a Niemcy stawiała w środku świata naukowego. Krytyczna metoda tego filozofa weszła do wszystkich dyscyplin, i tak teolog jak filolog, prawnik czy lekarz stawali się uczniami w kantowskiej szkole. Dla nauczycieli wszystkich fakultetów uniwersyteckich myśl Kanta stanowiła wyznacznik i sprawdzian naukowej rzetelności ${ }^{19}$.

Zdaniem Hasse Sdralek podkreślał konieczność poszukiwań historyczno-kościelnych przeciwko błędnemu redukcjonizmowi podejścia religijno-historycznego ${ }^{20}$. Broniąc wyjątkowej roli historii Kościoła w walce z modernistycznymi poglądami preferującymi przede wszystkim historię religii i psychologię religii, wrocławski Profesor odwoływał się do myśli Heinricha Schrörsa ${ }^{21}$ oraz Adolfa Harnacka ${ }^{22}$ i powtarzał jako metodologiczną dewizę zdanie tego pierwszego: ,historia Kościoła - tak, historia religii - nie"23. Historia religii w ściśle psychologicznym podejściu nie jest w stanie ująć czynników etyczno-społecznych w oglądzie całości życia Kościoła, ani tego, co typowe dla postaci Kościoła. Z powodu wyłącznie psychologicznego oglądu w ocenie wartości historycznej, historyk religii gubi związek między tymi postaciami i ich historycznym otoczeniem. Religijne formy wspólnotowe, które wywarły swój wpływ na poszczególne postaci, mogą być należycie ocenione tylko z punktu widzenia historii Kościoła. Historyk musi szukać przedmiotu swoich badań przede wszystkim w faktach, a nie w opisach przeżyć psychicznych. Sdralek nie pominął żadnej dziedziny, której zbadanie może służyć prawdzie historycznej: czy to historia chrześcijańskiej sztuki, liturgii, czy archeologia, czy też historia filozofii chrześcijańskiej stanowią niezbędną pracę wstępną w opisie historii pobożności chrześcijańskiej ${ }^{24}$. Odrzucał twierdzenie Harnacka, że chrześcijański dogmat $\mathrm{w}$ swojej koncepcji i swojej obudowie jest przeniesieniem greckiego ducha na grunt Ewangelii, i za pomocą historii Kościoła polemizował z poglądami tych postępowych historyków religii, którzy traktowali chrześcijaństwo jako synkretyzm idei buddyjskich, babilońskich, indyjskich

${ }^{19}$ Por. Bendel, Max Sdralek, s. 17. Bendel komentuje myśli Sdralka przedstawione w Die Stellung der Geschichte zur Philosophie und Naturwissenschaft. Rede zum Antritt des Rektorats der königlischen Akademie zu Münster am 15.Oktober 1887 gehalten, Münster 1887, 8-9.

${ }^{20}$ Por. Hasse, Die Aufgaben des Kirchengeschichtslehrers, s. 4-5.

${ }^{21}$ Por. H. Schrörs, Kirchen Geschichte und nich Religionsgeschichte, Freiburg im Breisgau 1905.

${ }^{22}$ Por. A. Harnack, Die Aufgabe der theologischen Facultäten und die algemeine Religionsgeschichte, Berlin 1901.

${ }^{23}$ Hasse, Die Aufgaben des Kirchengeschichtslehrers, s. 6, thum. własne.

${ }^{24}$ Por. tamże, s. 13-15. 
i egipskich ${ }^{25}$. Dla Sdralka pierwsze przykazanie naukowe wymagało korzystania ze źródeł: aby uzyskać bezstronną ocenę zjawisk, aby poszerzyć i pogłębić poznanie historyczne, należy sięgać po materiały źródłowe ${ }^{26}$.

W polemicznym wywodzie Hasse podaje racje Sdralkowej apologetyki: żądania usunięcia historii Kościoła z programu studiów uniwersyteckich mają częściową przyczynę w teologii ewangelickiej, która coraz bardziej relatywizuje pojęcie Kościoła i stara się zastąpić je religijno-psychologiczną koncepcją niewidzialnego królestwa Bożego. Różnorodność opinii na temat procesów kościelno-historycznych znajduje przeważnie wyjaśnienie w zasadniczo różnym podejściu metodologicznym, które ma swoje korzenie w założeniach filozoficznych i dogmatycznych. Uczciwość badań wymaga, aby uwzględnić ten fakt zróżnicowania podstaw krytyki. Jest oczywiste, że zwolennik Kantowskiej teorii poznania całkiem inaczej będzie oceniał zjawiska religijne niż reprezentant jakiegoś innego kierunku filozoficznego; właściwa interpretacja wydarzeń historycznych wymaga uwzględniania zasady przyczynowości ${ }^{27}$.

To radykalne przeciwstawienie dwóch sposobów badań historycznych, wykluczających się - jak mogłaby sugerować przyjęta zasada - w gruncie rzeczy ma charakter względny: Sdralek starał się przypomnieć jedynie o konieczności zachowania zasady pierwszeństwa historii Kościoła przed historią religii i psychologii ${ }^{28}$. W jego pracach opis czynników społeczno-kulturowych pomaga łatwiej dostrzec działanie Boga w historii świata. Jako wzorcowy przykład Hasse podaje mowę Sdralka na temat przyczyn, które wyjaśniają zwycięstwo chrześcijaństwa w Cesarstwie Rzymskim (Über die Ursachen, welche den Sieg des Christentums im römischen Reiche erklären, Rektoratsrede, Breslau 1907) ${ }^{29}$.

Oprócz podstaw epistemologicznych i podstawowej roli obiektywizmu poznawczego jako narzędzia w rzetelnych badaniach historyka Kościoła, Hasse - w badaniach Sdralka - podkreśla ważną funkcję personalistycznie zdefiniowanej i interpretowanej narracji historycznej. Materialistyczne ujęcie historii, w którym decydujące znaczenie przypisuje się działalności mas, powstało pod wpływem nowych nurtów społecznych, i jako jednostronne zostało odrzucone. W rzeczywistości historia Kościoła pozwala poznać wielkie osobowości jako inspiratorów zachodzących w świecie przemian. Właściwa ocena tych osobowości stanowi jedno z najtrudniejszych zadań w poszukiwaniach historycznych ${ }^{30}$. Sdralek nie bał się podjacc tych badań, w których szczegółowo analizował naturalne czynniki rozwoju papiestwa i dowodził, że nie można się obejść bez uwzględnienia bodźców nadprzyrodzonych ${ }^{31}$.

\footnotetext{
${ }^{25}$ Por. tamże, s. 15.

${ }^{26}$ Por. tamże, s. 17.

${ }^{27}$ Por. tamże, s. 6-7.

${ }^{28}$ Por. tamże, s. 5.

${ }^{29}$ Por. tamże, s. 8.

${ }^{30}$ Por. tamże, s. 10.

${ }^{31}$ Por. tamże, s. 11.
} 
Wśród narzędzi pracy rzetelnego historyka Kościoła nie może zabraknąć gruntownego przekładu źródeł obcojęzycznych. Zdaniem Sdralka nie wolno podejmować żadnej krytyki źródeł bez opanowania znajomości języka i to do tego stopnia, aby w spornych fragmentach przekładu móc zaproponować samodzielną i uzasadnioną opinię. Tłumaczenie tekstu nie może być wiarygodne bez wglądu do rękopisów. Wydaniem i przekładem muszą zająć się pracownicy wykwalifikowani filologicznie; jednak w interpretacji nie wolno przeceniać filologii ${ }^{32}$.

3. Historia Kościoła i personalizm w metodzie S. Siwca. W świetle zarysowanej metodologii badań historycznych prowadzonych przez profesora Sdralka spójrzmy na warsztat naukowy jego ucznia. Badając czynniki, które wpłynęły na powstanie i rozwój monastycyzmu egipskiego, Siwiec starał się zachować równowagę między motywami eschatologicznymi, dominującymi $\mathrm{w}$ tradycyjnych ujęciach zagadnienia, a eklezjologicznymi, w których ascetyczny ideał porzucenia świata znajduje uzasadnienie wspólnotowe i jak najbardziej doczesne. W całej swojej trylogii, zwłaszcza w pierwszej i drugiej jej części, śląski patrolog konsekwentnie podkreśla wspólnototwórczy charakter nurtu monastycznego i jego misyjne oddziaływanie na środowisko. Stereotypowe opinie, w których bezrefleksyjnie definiuje się genezę i rozwój fenomenu anachoretyzmu i cenobityzmu w kategoriach izolacji od świata i udowadnia przypadkowość determinującą wybór tej formy ascezy, należy odrzucić jako niezgodne $\mathrm{z}$ wynikami historycznego oglądu zjawiska monastycyzmu.

Nie bez znaczenia w poszukiwaniach śladów wrocławskiej szkoły historii Kościoła w warsztacie naukowym Siwca może być pozornie mało oryginalny sposób wyjaśniania monastycyzmu za pomocą analizy życia i twórczości jego najwybitniejszych przedstawicieli ${ }^{33}$. Personalizm w argumentacji historycznej pozwala uniknąc realnego niebezpieczeństwa determinizmu w odkrywaniu przyczyn i skutków tego fenomenu, który stanowił istotną część pierwotnego Kościoła.

Personalistyczny charakter metody badawczej Siwca przejawia się także w wierności detalom geograficznym stanowiącym istotny element tła historycznego przedstawianych postaci życia monastycznego. W biograficznym opisie postaci Hilariona (291-371) śląski badacz przekazał bogaty materiał poświęcony charakterystyce miejscowości narodzenia tego świętego mnicha ${ }^{34}$.

4. Krytyka źródeł w metodzie S. Siwca. Dzieło życia Siwca wymaga z pewnością dalszych analiz, które mogłyby pozwolić z większą pewnością

${ }^{32}$ Por. tamże, s. 18.

${ }^{33}$ Por. Schiwietz, Das morgenländische Mönchtum, Bd. 1, s. $41-43$ i 192-204; tamże, Bd. 2, s. 131-191; tamże, Bd. 3, s. 45-48, 84-92, 176-180, 278-280 i 400-407. Warto wspomnieć reedycję tomu pierwszego i drugiego monografii Siwca (Nabu Press 2010).

${ }^{34}$ Por. tamże, Bd. 2, s. 103-120. 
i precyzją umieścić jego dorobek w kręgu historycznej szkoły Maxa Sdralka. Warto zatem przyjrzeć się bliżej metodologii historii Kościoła, którą Siwiec zastosował w mniej znanych i omawianych artykułach publikowanych w języku polskim. Opracowanie Dogmatyczno-historyczny przyczynek z historii Kościoła egipskiego na temat historii sakramentu namaszczenia chorych - jak zaznacza autor w tytule artykułu - ma charakter dogmatyczno-historyczny. Opis stanu badań zagadnienia badacz rozpoczyna od krótkiego omówienia mało precyzyjnej źródłowo pracy Józefa Kerna De sacramento extremae unctionis tractatus dogmaticus. Siwiec sygnalizuje profesję i miejsce pracy autora wspomnianego opracowania, następnie zaznacza historyczny walor przedstawionych tam dowodów, w końcu podaje zasadniczy mankament w historycznych wywodach Kerna. Cel badawczy, jaki sobie wyznaczył Siwiec, polega na analizie tego brakującego świadectwa, którym jest koptyjska legenda o śmierci Panesniva, egipskiego męczennika z początku IV wieku ${ }^{35}$. Śląski historyk odwołał się do opracowania wydanego pod koniec XVIII w. w Rzymie przez augustianina Antonia Agostina Giorgiego: De miraculis Santi Coluthi et reliquiis Santi Panesniv martyrum thebaica fragmenta duo, alterum auctius, alterum nunc primus editum: omnia a Museo Borgiano deprompta et illustrata opera et studio F. Augustini Antonii Georgii Eremitae Augustiniani (Romae 1793) ${ }^{36}$. Siwiec nie mógł znać opracowania Waltera Tilla, który poszerzył dzieło Giorgiego, dołączając krytyczne wydanie niepublikowanych wcześniej fragmentów manuskryptów z wiedeńskiej Biblioteki Narodowej. Opis męczeństwa Panesniva został zamieszczony w publikacji Tilla ${ }^{37}$. Artykuł Siwca zawiera krótki komentarz etymologii koptyjskiego imienia Panesniv, na podstawie którego można przyjąć znajomość języka koptyjskiego autora ${ }^{38}$. W dalszym ciagu analiz historyk będzie korzystał również ze znajomości języka greckiego ${ }^{39}$. Siwiec zaznacza brak imienia tego męczennika w kalendarzu Kościoła egipskiego, a jako uzasadnienie lakuny podaje wzmiankę Euzebiusza z Cezarei ${ }^{40}$ na temat wielkiej liczby anonimowych męczenników chrześcijańskich ${ }^{41}$.

${ }^{35}$ Por. T. Baumeister, Martyr invictus, w: The Coptic Encyclopedia, ed. A.S. Atiya, vol. 6, New York 1991, 124, http://ccdl.libraries.claremont.edu/cdm/singleitem/collection/cce/id/1512/rec/1 [dostęp 07.07.2013]; A.A. Giorgi, De miraculis Sancti Coluthi et reliquiis actorum Sancti Panesniv martyrum thebaica fragmenta duo..., Rome 1793, 178-193.

${ }^{36}$ Por. Siwiec, Dogmatyczno-historyczny przyczynek, s. 236.

${ }^{37}$ Por. W. Till, Koptische Heiligen und Martyrerlegenden, vol. 1, OCA 102, Rome 1935, 94106 (tekst koptyjski: s. 94-101; przekład niemiecki, s. 101-106), http://suciualin.files.wordpress. com/2012/01/till-koptische-heiligen-und-martyrerlegenden-1.pdf [dostęp: 07.07.2013].

${ }^{38}$ Por. Siwiec, Dogmatyczno-historyczny przyczynek, s. 236, nota 2; Siwiec tylko jeden raz użył archaicznej formy „koptycki”, zamieniając ją w dalszych swoich analizach na „koptyjski”.

${ }^{39}$ Por. tamże, s. 240-241.

${ }^{40}$ Por. Eusebius Caesariensis, HE VIII 9.

${ }^{41}$ Por. Siwiec, Dogmatyczno-historyczny przyczynek, s. 236-237. 
Polemizując z opinią Giorgiego, Siwiec uzasadnia bardziej prawdopodobną hipotezę lokalizacji miejscowości pochodzenia świętego oraz miejsca jego śmierci i wskazuje miasto Khebs w Dolnym Egipcie; precyzuje także przedział czasowy męczeństwa, sugerując lata 306-313. W badaniach historycznych Siwca analizy danych chronologicznych i geograficznych w przekazie legendarnym odgrywają istotną rolę ${ }^{42}$ i można je zakwalifikować jako przejaw wspomnianego już wątku personalistycznego. Równie ważny okazuje się komentarz literacki badanego tekstu, na podstawie którego śląski historyk precyzyjnie wskazuje na Juliusza z Khebs jako autora przekazu ${ }^{43}$. Następnie z opisu męczeństwa Panesniva Siwiec wydobywa interesujące wątki teologiczne: najpierw chrystologiczne podłoże biblijnego polecenia zawartego w Jk 5, 14-15; potem jego somatyczny aspekt, w przypadku gdyby zaproponowano interpretację redukującą chorobę do słabości w znaczeniu jedynie moralnym; w końcu opisuje istotne rozróżnienie między charyzmatycznym namaszczeniem w celu uleczenia z choroby cielesnej, na co pozwala Panesnivowi jego urząd diakona, a zarezerwowanym dla kapłanów sakramentem, w którym także odpuszczone zostają grzechy. Koptyjska legenda, w artykule konsekwentnie nazywana aktami męczeńskimi, stanowi dla Siwca najstarsze świadectwo, w którym Kościół egipski rozróżnia między sacramentum a sacramentale ${ }^{44}$. Jako potwierdzenie argumentu śląski historyk zaznacza, że to zróżnicowanie teologiczne, znane i praktykowane w obrzędach koptyjskich chrześcijan, opisał także Palladiusz w relacji ze swojej podróży do egipskich mnichów pod koniec IV w. Jego Historia Lausiaca stanowi jedno z najpopularniejszych w świecie starożytnym dzieł hagiograficznych. Siwiec powołuje się na Palladiuszowe przykłady charyzmatycznego uzdrawiania chorych przez mnichów ${ }^{45}$, analizuje istotne różnice teologiczne w modlitwach odmawianych nad chorymi, które znajdują się w Euchologium biskupa Serapiona z Thmuis (Sakramentarz Serapiona) ${ }^{46}$ oraz przytacza nieco dłuższy komentarz do interesującego fragmentu na temat namaszczenia chorych z 2. homilii Orygenesa-Rufina do Księgi Kapłańskiej ${ }^{47}$. Uzupełnieniem w argumentacji teologiczno-historycznej są przesłanki, w których Siwiec dowodzi znajomości obrzędowości Kościołów wschodnich oraz „cerkwi ruskiej”48. Powołując się na badania Probsta ${ }^{49}$, Siwiec nie odrzuca hipotezy, w myśl której o sakramencie namaszczenia chorych rzadko pisano i mówiono ze względu na obowiązek zachowania disciplina arcani, chociaż

\footnotetext{
${ }^{42}$ Por. tamże, s. 237.

${ }^{43}$ Por. tamże, s. 237, nota 3.

${ }^{44}$ Por. tamże, s. 238.

${ }^{45}$ Por. tamże, s. 239-240; Palladius, Historia Lausiaca XII 18.

${ }^{46}$ Por. Siwiec, Dogmatyczno-historyczny przyczynek, s. 240-242.

${ }^{47}$ Por. tamże, s. 243-244.

${ }^{48}$ Por. tamże, s. 243.

${ }^{49}$ Por. F. Probst, Sakramente und Sakramentalien in den drei ersten christlichen Jahrhunderten,
} Tübingen 1892, 373-374. 
trudno udowodnić istnienie tego prawa $\mathrm{a}^{50}$. Ubóstwo przekazów historycznych z większą pewnością można uzasadnić brakiem kontrowersji teologicznych w kwestii tego namaszczenia ${ }^{51}$.

Kolejny artykuł Siwca zamieszczony w lwowskim „Przeglądzie Teologicznym" pochodzi z 1926 r., powstał w Rybniku ${ }^{52}$ i prawdopodobnie został zredagowany w języku polskim pod tytułem Nowy sposób wyjaśnienia tekstu 1 Kor. 7, 36-3853. Śląski badacz zajął się szeroko dyskutowaną kwestią egzegezy myśli ascetycznej św. Pawła. Jako historyk i egzegeta biblijny, Siwiec zaznacza, że podstawą zaproponowanego przez siebie tłumaczenia są jego studia nad starożytnym ascetyzmem i monachizmem ${ }^{54}$. Śląski badacz podaje najpierw tekst grecki i tłumaczenie Wulgaty, wskazując istotne punkty w egzegezie biblijnego fragmentu ( $\tau ı \varsigma$ i $\pi \alpha \rho \theta \varepsilon ́ v o \varsigma ~ \alpha \nu ̉ \tau o \widehat{)}$ ), następnie poddaje krytyce dotychczasowe interpretacje (ojciec i córka; narzeczony i narzeczona; mężczyzna i kobieta żyjący wspólnie jak brat z siostrą - $\sigma v v \varepsilon i ́ \sigma \alpha \kappa \tau o$ na podstawie albo zwykłego postanowienia życia w stanie dziewiczym albo też złożonego ślubu czystości) z precyzyjnym wyszczególnieniem różnic logicznych i filologicznych ${ }^{55}$. Zdaniem Siwca nie wolno pomijać w komentarzu kontekstu niewolnictwa (por. 1Kor 7, 21), a w konsekwencji i takiej teorii, w której św. Paweł zwracałby się do neofity i jego niewolnicy. Małżeństwo nawróconego dominus, czy patronus z należącą do niego dziewicą nie byłoby zabronione w Kościele, mogło jedynie natrafić na przeszkody prawa rzymskiego i obyczajów społeczeństwa pogańskiego (zalegalizowany konkubinat, ale nie pełnoprawne connubium) ${ }^{56}$. Należy podkreślić, że w swojej argumentacji Siwiec

\footnotetext{
${ }^{50}$ Por. Siwiec, Dogmatyczno-historyczny przyczynek, s. 245.

${ }^{51}$ Por. tamże, s. 246.

${ }^{52}$ Sam Siwiec wskazuje Rybnik jako miejsce redakcji artykułu, por. tenże, Nowy sposób wyjaśnienia tekstu 1 Kor. 7, 36-38, s. 239.

${ }^{53}$ Niemiecki przekład tego artykułu: S. Schiwietz, Eine neue Auslegung von 1 Kor 7,36-38, ThG 19 (1927) 1-14. 1Kor 7, 36-38 w przekładzie Biblii Tysiąclecia: ,Jeżeli ktoś jednak uważa, że nieuczciwość popełnia wobec swej dziewicy, jako że przeszły już jej lata i jest przekonany, że tak powinien postąpić, niech czyni, co chce: nie grzeszy; niech się pobiorą! Lecz jeśli ktoś, bez jakiegokolwiek przymusu, w pełni panując nad swoją wolą, postanowił sobie mocno w sercu zachować nietkniętą swoją dziewicę, dobrze czyni. Tak więc dobrze czyni, kto poślubia swoją dziewicę, a jeszcze lepiej ten, kto jej nie poślubia". Autor lakonicznego komentarza zamieszczonego w wydaniu Biblii Tysiąclecia w przypisie do 1Kor 7, 36-38 wydaje się nie znać opracowania Siwca i ogranicza interpretację egzegetyczną Pawłowego tekstu do zaledwie dwóch najczęściej podawanych możliwości. Komentarz w Biblii Tysiąclecia do 1Kor 7, 36-38: „Istnieją dwie interpretacje tego trudnego tekstu: 1. chodzi o pewnego ojca stojącego wobec zagadnienia wydania lub niewydania za mąż córki, która jest już nie pierwszej młodości; 2. chodzi o dziewicę, która - by strzec skutecznie swej czystości - oddaje się w opiekę jakiemuś znanemu z uczciwości mężczyźnie. Przy obydwu tłumaczeniach powstają jednak trudności logiczne, filologiczne i historyczne".

${ }^{54}$ Por. Siwiec, Nowy sposób wyjaśnienia tekstu 1 Kor. 7, 36-38, s. 225.

${ }_{55}^{55}$ Por. tamże, s. 227-233.

${ }^{56}$ Por. tamże, s. 233.
} 
konsekwentnie i umiejętnie posługuje się dowodami z Ojców Kościoła i definiuje swoje opinie na podstawie argumentu patrystycznego, o czym zapominali zwykle prezentowani egzegeci. Jak zauważa Siwiec, Ojcowie Kościoła stosunkowo późno zajęli się omawianym przez Pawła problemem. Zgodnie z alegoryczną interpretacją egzegetyczną jedni twierdzili, że w 1Kor 7, 36-37 chodzi o osoby mające wybrać między małżeństwem a dziewictwem, inni zaś jednoznacznie przyjmowali w określeniach $\tau \iota \varsigma$ i $\pi \alpha \rho \theta \varepsilon ́ v o \varsigma ~ \alpha \nu ̉ \tau o \hat{~ o j c a ~ i ~ j e g o ~}$ niezamężną córkę ${ }^{57}$. Tak istotne różnice $\mathrm{w}$ patrystycznej interpretacji tekstu biblijnego Siwiec tłumaczy ciągle żywym wpływem poglądów pogańskich nieprzychylnych małżeństwu wolnej kobiety z niewolnikiem lub wyzwoleń$\mathrm{cem}^{58}$. Egzegeza patrystyczna podlegała zatem oddziaływaniu obyczajowości kształtowanej przez prawo rzymskie ${ }^{59}$. Po przedstawieniu argumentacji patrystycznej Siwiec wraca raz jeszcze do analizy porównawczej i podaje wersje Pawłowego tekstu w przekładzie koptyjskim ${ }^{60}$, etiopskim, ormiańskim i syryjskim, podkreślając oryginalne wyrażenia i ich znaczenie semantyczne ${ }^{61}$. Tylko w wersji syryjskiej, która zdaniem Siwca jest bardzo dowolną parafrazą, analizowane pojęcia oznaczają ojca i jego córkę ${ }^{62}$.

\section{$* * *$}

Konkludując, należy przypomnieć, że celem przedstawionego opracowania była prezentacja naukowego dorobku mało znanego wśród polskich badaczy śląskiego historyka Kościoła i teologa ks. dra Stefana Siwca. Podjęto próbę charakterystyki jego metody badawczej, którą zainicjowana została i była rozwijana w XIX i XX w. we „wrocławskiej szkole historycznej”. Akcentowanie roli analiz historyczno-filologicznych, świadomość konieczności opanowania języków klasycznych i orientalnych niezbędna w pracy $\mathrm{z}$ tekstami źródłowymi miały z pewnością swoje źródło w inspirującej twórczości jego wrocławskiego profesora Maxa Sdralka. W argumentacji uderza mozolna wnikliwość poszukiwań i pieczołowitość w stawianej diagnozie, dzięki którym Siwiec mógł swobodnie poruszać się w obszarze zarówno studiów nad tekstami biblijnymi, jak i ich historyczną aplikacją w tradycji monastycznej. W rzetelnych badaniach historyka Kościoła, czego uczył swoich uczniów Sdralek, podstawową rolę odgrywa obiektywizm poznawczy. Stwierdzamy, że Siwiec nie podejmuje tematyki hermeneutyki historii Kościoła, ale ,praktycznie" stara się wykorzystać teorię przekazaną przez swojego mentora. W uwagach krytycznych metody Siwca i w jego analizach źródeł monastycyzmu

\footnotetext{
${ }^{57}$ Por. tamże, s. 235-236.

${ }^{58}$ Por. Constitutiones Apostolorum VIII 32.

${ }^{59}$ Por. Siwiec, Nowy sposób wyjaśnienia tekstu 1 Kor. 7, 36-38, s. 236.

${ }^{60}$ Tym razem Siwiec używa już formy „koptyjski”.

${ }^{61}$ Por. tamże, s. 237-238.

${ }^{62}$ Por. tamże, s. 238.
} 
wschodniego należy podkreślić brak aspektu religioznawczego. Mało znany artykuł Siwca poświęcony orygenesowskim wpływom w eschatologii św. Jana Chryzostoma (Die Eschatologie des heiligen Johannes Chrysostomus und ihr Verhältnis zu der origenistischen) nie został do tej pory omówiony i z pewnością wymaga badań specjalistów.

\author{
STEPHAN SCHIWIETZ (SIWIEC) \\ - PUPIL OF MAX SDRALEK
}

\title{
(Summary)
}

Stefan Schiwietz (Stefan Siwiec), 1863-1941 - a Roman Catholic priest, Doctor of Theology, historian of the Eastern Orthodox Church, pedagogue - was born in Miasteczko Śląskie (Georgenberg) on $23^{\text {th }}$ August 1863 . He studied theology at the University of Wrocław for 3 years (1881-1884) under H. Laemmer, F. Probst, A. König and M. Sdralek, among others, and then continued his theological studies in Innsbruck (1884-1886), where he was a pupil of J. Jungmann and G. Bickell. The seminarist spent two years (1885-1886) in Freising in Bavaria, where in 1886 he took his holy orders. Siwiec published his doctoral thesis in Wrocław in 1896, so at the time when Sdralek took the chair of Church History. The subject of the Silesian scholar's dissertation concerned the monastic reform of Theodore the Studite De S. Theodoro Studita reformatore monachorum Basilianorum. Siwiec combined his didactic work as a religious and mathematics teacher in the public middle school in Racibórz with his academic studies on the history of Eastern Orthodox Christianity, especially on monasticism. The results of his research were published both in German and in Polish. His most significant work is a three-volume monograph Das morgenländische Mönchtum (Bd. 1: Das Ascetentum der drei ersten christl. Jahrhunderte und das egyptische Mönchtum im vierten Jahrhundert, Mainz 1904; Bd. 2: Das Mönchtum auf Sinai und in Palästina im 4 Jahrhundert, Mainz 1913; Bd. 3: Das Mönchtum in Syrien und Mesopotamien und das Aszetentum in Persien vierten Jarhundert, Mödling bei Wien 1938) on the history of the beginnings and development of Oriental monasticism in Egypt, Palestine, Syria and Persia, until the $4^{\text {th }}$ century, which up to the present day has been cited in the world Patristic literature. Yet, Siwiec's academic work still remains little known, especially in the circle of historians of antiquity and Polish patrologists. The equally little known figure of Max Sdralek, another Silesian (coming from Woszczyce) priest and academic, Rector of University of Wrocław, provides a significant context with the research methodology which this eminent scholar initiated, developed and tried to pass down to his pupils, among whom was also Stefan Siwiec. Sdralek strictly demanded that the principle of the priority of Church history over history of religion and psychology should be kept. In his works a description of socio-cultural factors and natural conditions determining the process of development of Christianity enables to see in a much 
clearer way how God's plan has unfolded in history. The mutual dependence of Sdralek and Siwiec, the similarities and differences in their ways of studying and understanding Church history still remains an issue worth further exploration.

Key words: S. Siwiec, M. Sdralek, History of the Eastern Church, Oriental Monasticism, „Wrocław School of History”.

Slowa kluczowe: S. Siwiec, M. Sdralek, historia Kościoła Wschodniego, wschodni monastycyzm, ,wrocławska szkoła historyczna”.

\section{BIBLIOGRAFIA}

\section{Literatura źródłowa}

Schiwietz (SiwIEc) S., Das morgenländische Mönchtum (Bd. 1: Das Ascetentum der drei ersten christl. Jahrhunderte und das egyptische Mönchtum im vierten Jahrhundert, Mainz 1904; Bd. 2: Das Mönchtum auf Sinai und in Palästina im 4 Jahrhundert, Mainz 1913; Bd. 3: Das Mönchtum in Syrien und Mesopotamien und das Aszetentum in Persien vierten Jarhundert, Mödling bei Wien 1938.

Schiwietz S., De S. Theodoro Studita reformatore monachorum Basilianorum, Vratislav 1896.

Schiwietz S., Die Eschatologie des hl. Johannes Chrysostomus und ihr Verhältnis zu der origenistischen, Mainz 1914.

Schiwietz S., Eine neue Auslegung von 1 Kor 7,36-38, ThG 19 (1927) 1-14.

SDRALEK M., Die Stellung der Geschichte zur Philosophie und Naturwissenschaft. Rede zum Antritt des Rektorats der königlischen Akademie zu Münster am 15.Oktober 1887 gehalten, Münster 1887.

SiwIEC S., Dotad nieuwzględnione świadectwo dotyczqce sakramentu olejem namaszczenia. Dogmatyczno-historyczny przyczynek z historii Kościoła egipskiego, PT 5 (1924) 236-246.

SiwIEC S., Nowy sposób wyjaśnienia tekstu 1 Kor. 7, 36-38, PT 7 (1926) 225-239.

\section{Autorzy starożytni}

Constitutiones Apostolorum, ŹMT 42 [wyd. grecko-polskie, oprac. A. Baron - H. Pietras, thum. S. Kalinkowski], Kraków, Kraków 2007 = SCL 2, 1-293.

Eusebius CAesariensis, Historia ecclesiastica, ŹMT 70 [wyd. grecko-polskie, oprac. H. Pietras, tłum. A. Caba na podstawie tłum. A. Lisieckiego], Kraków 2013.

\section{Opracowania}

AвMEIER H.-L., Sdralek, Max Lukas, http://kulturportal-west-ost.eu/biographies/sdralek-max-lukas-2/ [dostęp: 07.07.2013].

Baumeister T., Martyr invictus, w: The Coptic Encyclopedia, ed. A.S. Atiya, vol. 6, New York 1991, 124.

Bendel R., Max Sdralek. Der Begründer der Breslauer kirchenhistorischen Schule, „Archiv für schlesische Kirchengeschichte" 55 (1997) 11-38.

Giorgi A.A., De miraculis Santi Coluthi et reliquiis Santi Panesniv martyrum thebaica fragmenta duo, alterum auctius, alterum nunc primus editum: omnia a Museo Borgiano deprompta et illustrata opera et studio F. Augustini Antonii Georgii Eremitae Augustiniani, Romae 1793. 
Gouillard J., [rec.] Schiwietz (Stephan), Das morgenländische Mönchtum. Dritter Band: Das Mönchtum in Syrien und Mesopotamien und das Aszetentum in Persien vierten Jarhundert, Mödling bei Wien 1938, EtByz 1 (1943) 285-286

Harnack A., Die Aufgabe der theologischen Facultäten und die algemeine Religionsgeschichte, Berlin 1901.

Hasse F., Die Aufgaben des Kirchengeschichtslehrers nach Professor Max Sdralek, Schlesisches Pastoralblatt 35, Breslau 1914.

JEDIN H., Kirchenhistoriker aus Schlesien in der Ferne, „Archiv für schlesische Kirchengeschichte" 11 (1963) 243-259.

Myszor W., Ks. dr Stefan Siwiec jako badacz wschodniego monastycyzmu, w: Kultura edukacyjna na Górnym Ślasku, red. A. Barciak, Katowice 2002, 296-305.

Proвst F., Sakramente und Sakramentalien in den drei ersten christlichen Jahrhunderten, Tübingen 1892.

Schiel H., Max Sdralek, der Begründer der Breslauer Kirchengeschichtsschule, im Bannkreis von Xaver Kraus, Teil 1, „Archiv für schlesische Kirchengeschichte” 35 (1977) 239-284.

SCHRÖRS H., Kirchen Geschichte und nich Religionsgeschichte, Freiburg im Breisgau 1905.

Historia monastycyzmu orientalnego. W 70 rocznicę śmierci ks. dra Stefana Siwca (Schiwietz) 1863-1941, red. A. Uciecha, SACh SN 16, Katowice 2014.

Till W., Koptische Heiligen und Martyrerlegenden, vol. 1, OCA 102, Rome 1935.

Weitlauff M., Sdralek Max, w: Neue Deutsche Biographie 24, Berlin 2010, 103.

WitTig J., Max Sdralek, Schlesier 1, Schlesier des 19. Jahrhunderts, hrsg. von F. Andreae - M. Hippe - O. Schwarzer, Breslau 1922, 130-133. 